\title{
Therapy for patients with burns - an integrating review
}

DRosadélia Malheiros Carboni'

(iD) Giulia Luiza Santos ${ }^{2}$

(DIvo Celso Carboni Júnior ${ }^{3}$

(DDaniela Fátima Teixeira Silva ${ }^{1}$

(D) Sandra Kalil Bussadori

DiD Kristianne Porta Santos Fernandes ${ }^{1}$

(D) Raquel Agnelli Mesquita -Ferrari ${ }^{1}$

1. Pós-graduação em Biofotônica aplicada às Ciências da Saúde, Universidade Nove de Julho (Uninove) São Paulo, SP, Brasil 2. Iniciação científica 3. Pronto Socorro Municipal de Itapevi, Itapevi, SP, Brasil

http://dx.doi.org/10.1590/1806-9282.65.11.1405

\section{SUMMARY}

OBJECTIVE: to identify, through an integrative review, national studies published over the last ten years highlighting products and therapies used in burns.

METHODS: integrative research with studies published in the last ten years. Including clinical studies describing the use of the already established or innovative therapies in burns and the results obtained, published in national journals in the last ten years. Excluding articles published before 2007 and those that did not present results regarding the use of products in burns.

RESULTS: ten articles that met the inclusion criteria were selected. Collagenase, $1 \%$ silver sulfadiazine, and porous cellulose membrane were some of the therapies cited.

CONCLUSION: the casuistry was low; however, the good results obtained with porous cellulose membrane and silver nanocrystalline dressing are highlighted, since they were used in a larger number of patients in the studies evaluated.

KEYWORDS: Burns. Burn units. Wound Healing. Debridement. Bandages.

\section{INTRODUCTION}

Burns are secondary injuries from accidents involving thermal, chemical, or electrical energy capable of producing excessive heat, damaging the skin and/or other tissues, leading to cell death. They are classified according to the depth of the site affected, as first, second, or third grade. First degree burns (Figure 1A) affect the epidermis and do not form blisters; they cause pain, hyperemia, and edema. Second-degree burns (Figure 1B) affect the epidermis and the dermis, form- ing blisters; they can be superficial, with the basis of the blister pink, wet and painful, or deep, with the basis of the blister white, dry and less painful'. Third-degree burns (Figure 1C) affect even deeper structures; there is no pain due to the destruction of the nerve endings; there is no capillary return, and blood vessels are compromised due to coagulation; there is no spontaneous regeneration, grafting is indicated and, when there is healing, there is retraction of edges ${ }^{2-4}$. 
FIGURE 1. ILLUSTRATIVE IMAGES OF DIFFERENT DEGREES OF BURNS. A: FIRST-DEGREE BURN; B: SECONDDEGREE BURNS; C: THIRD-DEGREE BURNS; SOURCE: PRIVATE FILE.
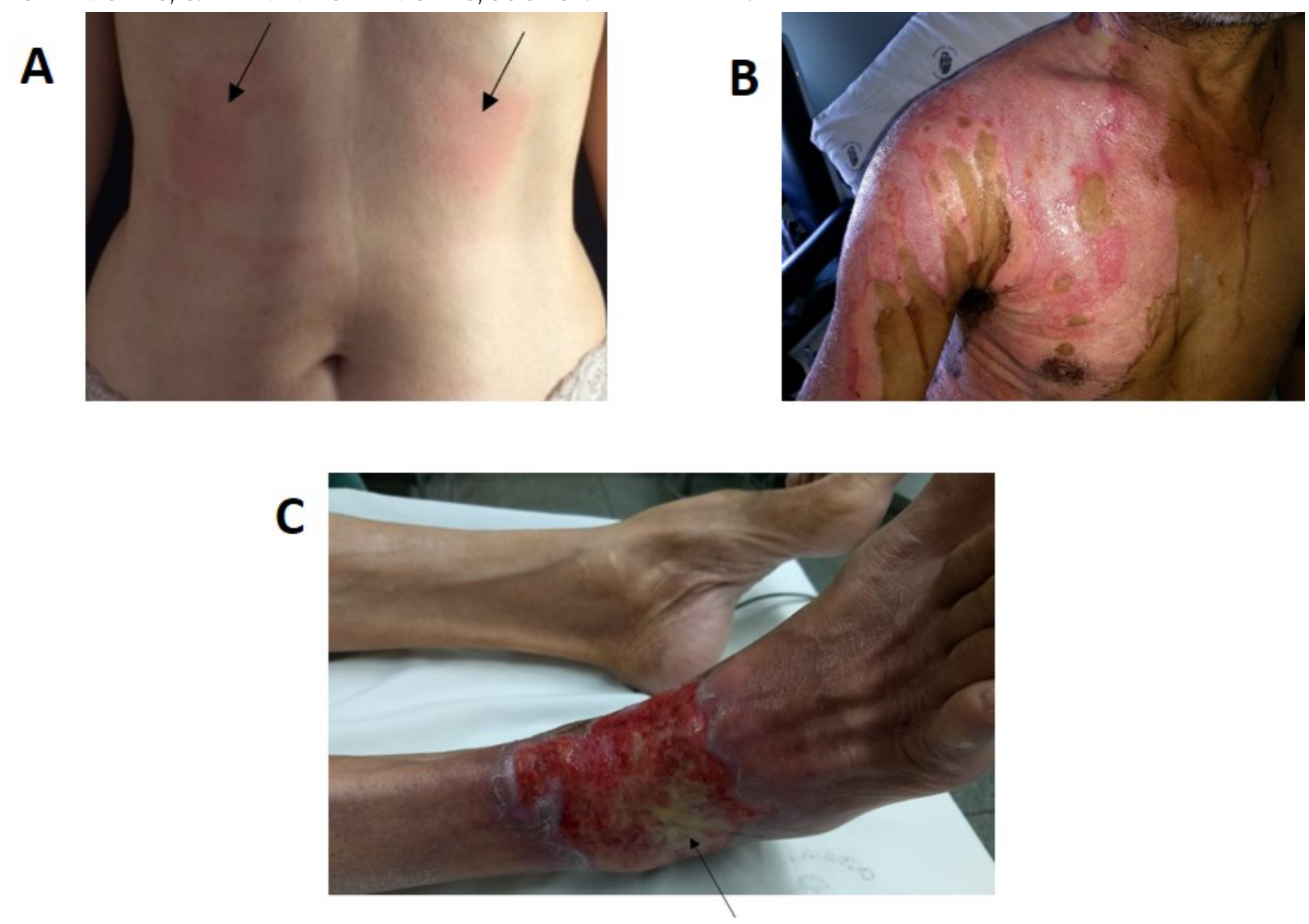

The therapy of burned patients has always been a global challenge, both due to the complexity of lesions and to the need for intensive and multidisciplinary care involving several health professionals, such as clinicians, intensivists, psychologists, nutritionists, physical therapists, and nurses with expertise in this area ${ }^{5}$. A complex wound raises the rates of morbidity and mortality, increases the overall costs of treatment (inputs and human resources), and leads to longer hospital stays ${ }^{6}$. The systemic treatment of burn patients focuses on reducing edema, maintaining hemodynamics and renal function, preventing or combating infections, preserving the viable tissues, protecting the microcirculation, strengthening innate defenses, and providing essential substrates to support viable tissues and recovery ${ }^{7}$.

The topical therapy appropriate to an injury due to burns considers the use of products that control bacterial growth, remove the devitalized tissue, and promote healing. ${ }^{8}$. Several studies mention the products used in the treatment of burns. One of them mentions that the first option of health institutions for the treatment of burns from the second degree is silver sulfadiazine $1 \%{ }^{9}$, a topical antimicrobial drug of the sulfanilamide class found in the presentation of a white, odorless, and soluble cream ${ }^{10}$. Another report mentions silver sulfadiazine at $1 \%$, cream or solution, and its combination with cerium nitrate, besides other preparations with silver ${ }^{11}$. Hyperbaric oxygen therapy for burns was also highlighted in a study ${ }^{7}$, as well as the use of hyaluronic acid (HA) ${ }^{12}$. HA is involved in several cellular functions, including cell proliferation, cell locomotion, and interactions with leukocytes. It is used clinically to treat articular disease and in ophthalmic surgical devices; some studies suggest benefits from using it in wound healing ${ }^{13}$.

Another paper highlighted silver sulfadiazine in the first 48-72 hours, topical chemical debridement until the necrotic tissue is removed, a topical product with a growth factor, surgery for removal of devitalized tissue, and bandage embedded in saline solution $^{8}$ Other authors have cited as topical agents, mostly antimicrobials, the associations between neomycin sulfate and bacitracin; between clostebol acetate and $5 \mathrm{mg}$ of neomycin sulfate and silver sulfadiazine $1 \%^{14}$. 
Other researchers have pointed out that in cases in which the burned surface area (BSA) is extensive, because of the greater complexity of therapy, other substances and techniques that stimulate and encourage healing must be used, such as heparin, papain, lidocaine, surgical treatment of autologous graft of the skin and/or debridement ${ }^{15}$.

In folk medicine, plants are used for the treatment of burns: Aloe barbadensis Mill (aloe vera), and Symphytum officinale (comfrey), which have healing action and are used generally in natura, as a poultice or decoction ${ }^{16}$. Aloe vera and comfrey are funded by the Ministry of Health for availability in the public health network and are part of the Brazilian Pharmacopoeia Phytotherapics List ${ }^{17,18}$.

Other authors mention the use of Silver Sulfadiazine $1 \%$, calcium alginate, hydrocolloid, petrolatum, and hydrogel, depending on the condition of the wound, with there is necrosis, exudate and/or bleeding ${ }^{14}$.

Due to the several options available on the market, more studies are necessary to define those that allow lower repair time, less retraction, lower probability of infection, and better pain control. Choosing an appropriate therapy for burns and hypoalgesia or analgesia is the goal of professionals who treat patients with this type of injury. Therefore, it is important to have scientific evidence to base adequate clinical behavior.

\section{OBJECTIVE}

To identify, by means of an integrative review, national studies published over the past ten years that highlight products and therapies used in burns.

\section{METHODS}

To build this integrative review, six distinct stages were followed ${ }^{19}$ :

1 - Research question: What therapies that have been cited in the literature for the treatment of lesions secondary to burns, in the last ten years?

2 - Inclusion criteria: We used all field studies that described the use of established or innovative therapies for burns and the results obtained and published in online Brazilian journals over the past ten years (2007 to 2017). Exclusion criteria: We excluded articles published before 2007, those who do not focus on the treatment of lesions secondary to burns, that did not present results regarding the use of products on burns, and those that described therapies used outside of Brasil.

3 - Categorization of studies: Extraction of information, database formation. The keywords were selected in accordance with the Health Sciences Descriptors (DeCs): burns, burns Units, healing, debridement, dressings. The relationship established between these words obeyed the following criteria: the search should relate three of them and, in the event of a negative result, relate two of them. The databases consulted were: SciELO, Lilacs, Medline-Bireme, and PubMed. The abstracts were read, and those relevant to the topic were selected for later indepth reading.

The search in SciELO retrieved 177 papers; of these, one was selected. The search in PubMed retrieved 39 papers, but none met the inclusion criteria. In Lilacs, the search retrieved 30 papers, and eight were selected. The papers that were not selected approached burns related to the quality of life, team, and work in Burns Units, development of products for skin lesions, analgesia, epidemiological aspects, and animal studies, and many were not used because they were published before 2007. Some papers were not selected because their full text was not available. The search on Medline-Bireme, linking the keywords, resulted in 26 papers, but none was used because they were about animal studies, or studies were before 2007, or studies that addressed matters not relevant to the subject, or studies without permission for full access. One paper was included from the references for another study. Thus, in total, ten papers were selected.

Four field studies were also discarded because, although they described the use of products in burn patients, they did not describe how these products influenced the repair of tissues. One mentioned the use of silver sulfadiazine $1 \%$ and papain ${ }^{20}$; another approached, in a case report, a patient with burns in several regions of the body and treatment with collagenase, silver sulfadiazine, among others, as needed: exudate, slough, bleeding ${ }^{21}$; another that described the use of products such as silver sulfadiazine, adaptic and carboxymethylcellulose in burned patients, ${ }^{5}$ and a final one that designed a guideline which included silver sulfadiazine at $1 \%$, silver sulfadiazine at $1 \%$ with cerium nitrate at $2.2 \%$ and essential fatty acid ${ }^{22}$. A study published in a na- 
FIGURE 2 . FLOWCHART OF THE RESULTS OF THE STUDY SELECTION PROCEDURE ROSADÉLIA MALHEIROS CARBONI
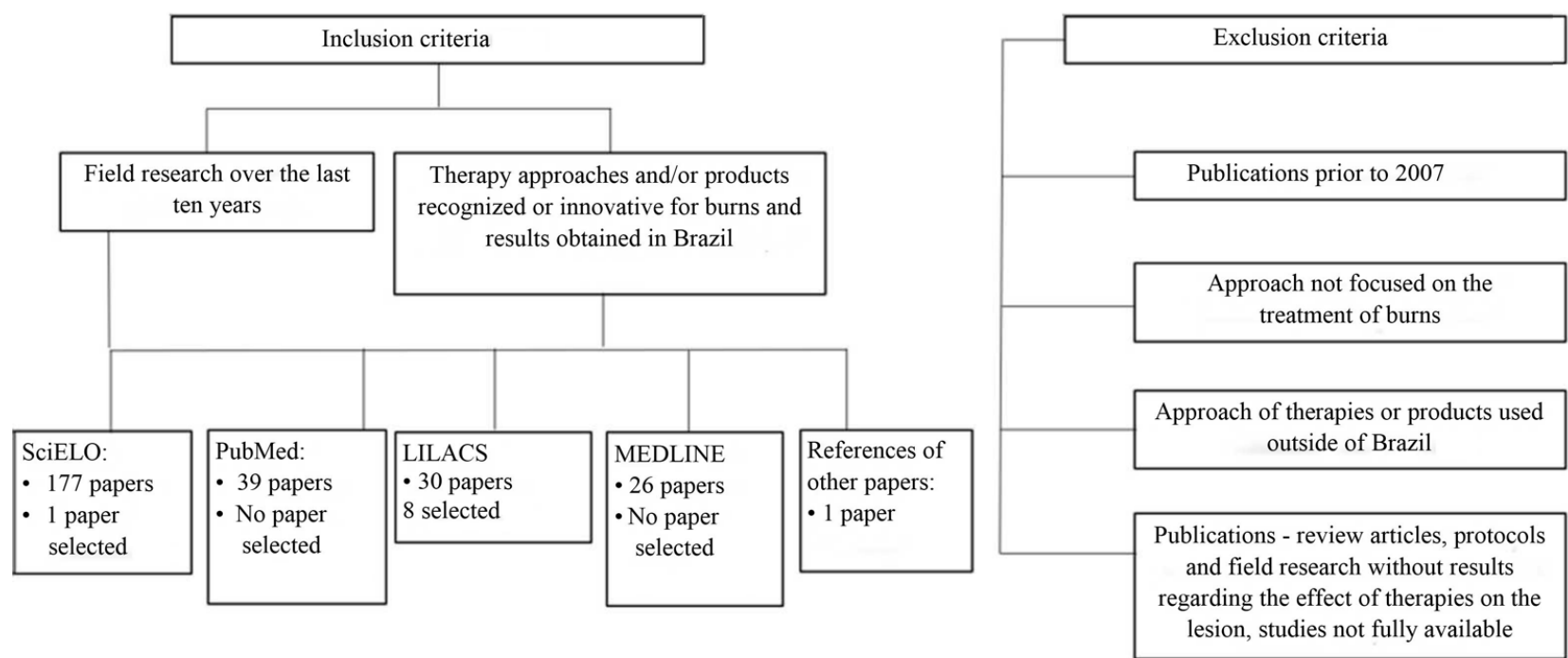

tional magazine reports the use of dermal regeneration matrix in burns and described the result, but it was developed in Lisbon, Portugal; therefore, it was not used in this study ${ }^{23}$. Below, a flowchart describes the results of the study selection procedure (Figure 2).

\section{RESULTS}

Based on the results obtained, we designed a figure compiling all the information from the selected studies, such as the author, title of the study, objective, type of research, the therapy used, and results. The research was conducted from April to June 2017.

FIGURE 3. INFORMATION FROM THE ARTICLES INCLUDED IN THE INTEGRATIVE REVIEW. ROSADÉLIA MALHEIROS CARBONI

\begin{tabular}{|c|c|c|c|c|c|}
\hline Authors & Title & Objective & Type of study & Therapy used & Results \\
\hline $\begin{array}{l}\text { Gonçalves } \\
\text { et al. }{ }^{24}, 2016\end{array}$ & $\begin{array}{l}\text { Comparação dos } \\
\text { efeitos do ácido hial- } \\
\text { urônico } 0,2 \% \text { e ácidos } \\
\text { graxos essenciais em } \\
\text { paciente com quei- } \\
\text { madura por fertilizante: } \\
\text { relato de caso. }\end{array}$ & $\begin{array}{l}\text { Compare the effects of } \\
\text { hyaluronic acid } 0.2 \% \text { and } \\
\text { essential fatty acids in a } \\
\text { patient with burns caused } \\
\text { by fertilizer: case report. }\end{array}$ & $\begin{array}{l}\text { A case report of a } \\
\text { patient with superficial } \\
\text { second-degree burns } \\
\text { and small areas of deep } \\
\text { second degree on both } \\
\text { hands caused by the } \\
\text { use of fertilizer, without } \\
\text { signs of infection or } \\
\text { other complications. }\end{array}$ & $\begin{array}{l}\text { Hyaluronic acid (Hyaluder- } \\
\text { min }^{\circledR}-\text { TRB Pharma) } \\
\text { Essential fatty acids (Skin- } \\
\text { basis }^{\circledR} \text { ) }\end{array}$ & $\begin{array}{l}\text { The hyaluronic acid } 0.2 \% \\
\text { cream was well tolerated by the } \\
\text { patient, without any incident of } \\
\text { local or systemic adverse events } \\
\text { identified during the study, with } \\
\text { better performance, in relation } \\
\text { to healing, than the essential } \\
\text { fatty acid (EFA) in the case } \\
\text { reported. }\end{array}$ \\
\hline $\begin{array}{l}\text { Moser et } \\
\text { al. }{ }^{25}, 2014\end{array}$ & $\begin{array}{l}\text { Uso de curativos } \\
\text { impregnados com } \\
\text { prata no tratamento } \\
\text { de crianças queimadas } \\
\text { internadas no Hos- } \\
\text { pital Infantil Joana de } \\
\text { Gusmão. }\end{array}$ & $\begin{array}{l}\text { Analyze the results of the } \\
\text { use of silver dressings in } \\
\text { the treatment of partial } \\
\text { burns. }\end{array}$ & $\begin{array}{l}\text { A cross-sectional epide- } \\
\text { miological study. }\end{array}$ & $\begin{array}{l}\text { Silver sulfadiazine 1\% } \\
\text { Nanocrystalline Silver }\end{array}$ & $\begin{array}{l}\text { Patients who used the silver } \\
\text { nanocrystalline dressing and } \\
\text { dressings associated with a } \\
\text { non-traumatic interface of the } \\
\text { wound made of absorbent foam } \\
\text { presented a lower reepitheliali- } \\
\text { zation time those who used the } \\
\text { silver sulfadiazine dressing. }\end{array}$ \\
\hline $\begin{array}{l}\text { Teles et al. }{ }^{\mathbf{2 6}}, \\
2012\end{array}$ & $\begin{array}{l}\text { Tratamento de que- } \\
\text { imadura de segundo } \\
\text { grau em face e pescoço } \\
\text { com heparina tópica: } \\
\text { estudo comparativo, } \\
\text { prospectivo e random- } \\
\text { izado. }\end{array}$ & $\begin{array}{l}\text { Assess the epithelization } \\
\text { time, pain, and infection } \\
\text { rate, comparing the use } \\
\text { of topical heparin to the } \\
\text { use of collagenase (control } \\
\text { group) in the treatment of } \\
\text { superficial face and neck } \\
\text { second-degree burns. }\end{array}$ & $\begin{array}{l}\text { A prospective study of } \\
\text { patients with superficial } \\
\text { second degree burns on } \\
\text { their faces and necks } \\
\text { from less than } 24 \text { hours. }\end{array}$ & $\begin{array}{l}\text { Topical heparin } \\
\text { Collagenase }\end{array}$ & $\begin{array}{l}\text { The results of this study showed } \\
\text { that the collagenase group } \\
\text { presented a shorter healing time } \\
\text { than the heparin group }(p<0.05) \text {. }\end{array}$ \\
\hline
\end{tabular}




\begin{tabular}{|c|c|c|c|c|c|}
\hline Authors & Title & Objective & Type of study & Therapy used & Results \\
\hline $\begin{array}{l}\text { Proto e } \\
\text { Gozzano } \\
201^{27}\end{array}$ & $\begin{array}{l}\text { Curativo de espuma } \\
\text { e silicone suave: uma } \\
\text { alternativa para o trata- } \\
\text { mento de queimadura } \\
\text { em mãos. }\end{array}$ & $\begin{array}{l}\text { Demonstrate the use of } \\
\text { soft foam and silicone } \\
\text { dressings as an alternative } \\
\text { in the treatment of hand } \\
\text { burns. }\end{array}$ & $\begin{array}{l}\text { A case report of a } \\
\text { patient with a second } \\
\text { degree burn in their left } \\
\text { hand by direct contact } \\
\text { with bike fumes. }\end{array}$ & $\begin{array}{l}\text { Soft foam and silicone } \\
\text { dressing }\end{array}$ & $\begin{array}{l}\text { The dressing of soft silicone } \\
\text { foam and is a good } \\
\text { treatment option for burns in } \\
\text { joint areas, such as the hand, } \\
\text { avoiding long immobilizations, } \\
\text { retractions, and sequelae }\end{array}$ \\
\hline $\begin{array}{l}\text { Vieira et } \\
\text { al. }^{\mathbf{2 8}}, 2017\end{array}$ & $\begin{array}{l}\text { Porous cellulose mem- } \\
\text { brane in the treatment } \\
\text { of burns. }\end{array}$ & $\begin{array}{l}\text { Review the concepts of } \\
\text { porous cellulose mem- } \\
\text { brane (PCM) dressing, } \\
\text { its use indications, and } \\
\text { demonstrate the clinical } \\
\text { results obtained. }\end{array}$ & $\begin{array}{l}\text { A prospective study in } \\
\text { patients with second } \\
\text { degree burns, superfi- } \\
\text { cial and deep, with an } \\
\text { average of } 12 \% \text { of body } \\
\text { surface area burned. }\end{array}$ & $\begin{array}{l}\text { Porous cellulose membrane } \\
\text { dressing }\end{array}$ & $\begin{array}{l}\text { Superficial second-degree burns } \\
\text { epithelialized satisfactorily in } \\
\text { seven days, without the need } \\
\text { to change the membrane. No } \\
\text { complications were observed, } \\
\text { such as wound infection, de- } \\
\text { layed healing, or early detach- } \\
\text { ment of the dressing. }\end{array}$ \\
\hline $\begin{array}{l}\text { Silva et al. }{ }^{29} \\
2017\end{array}$ & $\begin{array}{l}\text { Efeitos do tratamen- } \\
\text { to tópico com ácido } \\
\text { hialurônico 0,2\% em } \\
\text { queimadura de segun- } \\
\text { do grau: um relato de } \\
\text { experiência. }\end{array}$ & $\begin{array}{l}\text { Test the daily and } \\
\text { prolonged topical use of } \\
\text { hyaluronic acid } 0.2 \% \text { in the } \\
\text { healing of burns in elderly } \\
\text { patients, observing the fol- } \\
\text { lowing parameters: healing } \\
\text { time, presence or absence } \\
\text { of hypertrophic scars, } \\
\text { and the final aesthetic } \\
\text { effect resulting from the } \\
\text { treatment. }\end{array}$ & $\begin{array}{l}\text { Case reports of a } \\
\text { patient with a superficial } \\
\text { second-degree burn } \\
\text { and small areas of deep } \\
\text { second-degree burns. }\end{array}$ & $\begin{array}{l}\text { Hyaluronic acid } 0.2 \%(\text { Hya- } \\
\text { ludermin }^{\circledast} \text { - TRB Pharma) }\end{array}$ & $\begin{array}{l}\text { The data allow us to conclude } \\
\text { that the topical application of } \\
\text { HA } 0.2 \% \text { in burns of an elderly } \\
\text { patient helped to accelerate } \\
\text { healing, improved treatment } \\
\text { evolution, and aesthetic results. }\end{array}$ \\
\hline $\begin{array}{l}\text { Buelvas e } \\
\text { Ohana } \\
2016\end{array}$ & $\begin{array}{l}\text { Uso de Omiderm }{ }^{\circledast} \text { em } \\
\text { queimadura grave: } \\
\text { relato de caso. }\end{array}$ & $\begin{array}{l}\text { Report the case of a child } \\
\text { with severe burns attended } \\
\text { at the Burn Treatment } \\
\text { Center of the Municipal } \\
\text { Hospital Pedro II in Rio } \\
\text { de Janeiro, RJ, in which } \\
\text { treatment with Omiderm }{ }^{\circledR} \\
\text { was used. }\end{array}$ & $\begin{array}{l}\text { A case report of a } \\
\text { patient with } 1 \text { year and } \\
5 \text { months of age; } 31 \% \\
\text { of burned surface area } \\
\text { (BSA) by the Lund and } \\
\text { Browder rule. Most } \\
\text { burns were of deep } \\
\text { second degree, with } \\
\text { small areas of superficial } \\
\text { second degree. }\end{array}$ & $\begin{array}{l}\text { Omiderm }{ }^{\circledR}, \\
\text { Semi-biological skin substi- } \\
\text { tute, transparent, adherent, } \\
\text { and semipermeable }\end{array}$ & $\begin{array}{l}\text { After } 11 \text { days of treatment with } \\
\text { balneotherapy (cleaning of } \\
\text { wounds with running water and } \\
2 \% \text { chlorhexidine antiseptic, } \\
\text { debridement of necrotic tissue } \\
\text { and occlusive dressing) and } \\
\text { Omiderm }{ }^{\mathbf{R}} \text {, the child progressed } \\
\text { with clean and dry wounds, } \\
\text { without signs of inflammation, } \\
\text { with burns fully satisfactory } \\
\text { epithelialization of burns. }\end{array}$ \\
\hline $\begin{array}{l}\text { Calegari } \\
\text { e Queiroz } \\
\text { Venancio }^{31} \\
2012\end{array}$ & $\begin{array}{l}\text { O princípio da simili- } \\
\text { tude no tratamento de } \\
\text { queimaduras. }\end{array}$ & $\begin{array}{l}\text { Report the evolution of the } \\
\text { healing process in order } \\
\text { to disclose this practice, } \\
\text { which is one of the axes } \\
\text { of the National Policy on } \\
\text { Complementary and Inte- } \\
\text { grative Therapies (PNPIC) } \\
\text { in the SUS, as a possible } \\
\text { and necessary part of Fam- } \\
\text { ily Health strategies. }\end{array}$ & $\begin{array}{l}\text { Case reports } \\
\text { Patient } 1,7 \text { years old, } \\
\text { with first and sec- } \\
\text { ond-degree burns } \\
\text { on the face, ear lobe, } \\
\text { shoulder, chest, armpits, } \\
\text { and the proximal region } \\
\text { of the arm on the right } \\
\text { side. } \\
\text { Patient 2, } 42 \text { years old, } \\
\text { with first and second } \\
\text { degree burns on the } \\
\text { anterior region of the } \\
\text { right leg. }\end{array}$ & $\begin{array}{l}\text { A solution of } 2 \text { liters of } \\
\text { warm water and } 200 \mathrm{ml} \text { of } \\
\text { alcohol applied on the burn } \\
\text { with local compress }\end{array}$ & $\begin{array}{l}\text { In patient 1, on the 13th day of } \\
\text { treatment, complete restoration } \\
\text { and healing with good aspect } \\
\text { were noticed, with only a small } \\
\text { area of keloid only in the prox- } \\
\text { imal region of the right arm. In } \\
\text { patient 2, on the 16th day of the } \\
\text { homeopathic dressing, fully fa- } \\
\text { vorable evolution was observed, } \\
\text { considering the time elapsed } \\
\text { after the injury and the fact that } \\
\text { the lower limbs had varicose } \\
\text { veins, an important factor due } \\
\text { to their size; there was also } \\
\text { centripetal healing. }\end{array}$ \\
\hline $\begin{array}{l}\text { Costa Filho } \\
\text { et al. }{ }^{32}, 2012\end{array}$ & $\begin{array}{l}\text { Tratamento ambula- } \\
\text { torial de queimaduras } \\
\text { com prata nanocrista- } \\
\text { lina em malha flexível: } \\
\text { uma alternativa } \\
\text { terapêutica. }\end{array}$ & $\begin{array}{l}\text { To evaluate treatment } \\
\text { efficacy and duration on } \\
\text { patients in outpatient } \\
\text { treatment with nanocrys- } \\
\text { talline silver in flexible } \\
\text { mesh in the Burn Treat- } \\
\text { ment Unit of the Regional } \\
\text { Hospital of Sorocaba. }\end{array}$ & $\begin{array}{l}\text { Case reports of patients } \\
\text { with second degree } \\
\text { burns affecting between } \\
1 \% \text { and } 2 \% \text { of the body } \\
\text { surface, according to } \\
\text { the table of Lund and } \\
\text { Browder. }\end{array}$ & $\begin{array}{l}\text { Acticoat }{ }^{\circledR} \text { Flex - Smith and } \\
\text { Nephew (flexible polyester } \\
\text { mesh, with nanocrystalline } \\
\text { silver, with broad-spectrum } \\
\text { antimicrobial action) }\end{array}$ & $\begin{array}{l}\text { The average time of treatment } \\
\text { was } 13 \text { days. The flexible polyes- } \\
\text { ter mesh proved to be effective } \\
\text { in the healing of burns and good } \\
\text { alternative therapy. }\end{array}$ \\
\hline 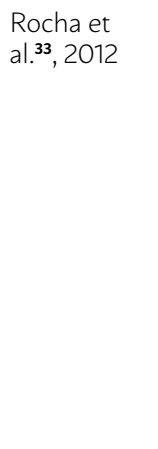 & $\begin{array}{l}\text { Avaliação comparativa } \\
\text { do uso de hidroalgi- } \\
\text { nato com prata e o } \\
\text { curativo convencional } \\
\text { em queimaduras de } \\
\text { segundo grau. }\end{array}$ & $\begin{array}{l}\text { Compare the conventional } \\
\text { treatment of second-de- } \\
\text { gree burns, superficial } \\
\text { (four-layer dressing) and } \\
\text { deep (four-layer dressing + } \\
1 \% \text { silver sulfadiazine), and } \\
\text { the use of silver hydro-al- } \\
\text { ginate regarding the fol- } \\
\text { lowing criteria: pain, burn } \\
\text { evolution, and practicality } \\
\text { of use. }\end{array}$ & $\begin{array}{l}\text { A prospective study } \\
\text { with patients with } \\
\text { superficial or mixed } \\
\text { (deeper superficial) } \\
\text { second degree burns } \\
\text { with burned surface } \\
\text { area (BSA) of up to } 3 \% \text {, } \\
\text { on upper limbs, lower } \\
\text { limbs, and thorax. }\end{array}$ & $\begin{array}{l}\text { Dressing 1: four layers, } \\
\text { made of rayon gauze, burn } \\
\text { gauze (cheese type), absor- } \\
\text { bent cotton and tape } \\
\text { Dressing 2: four layers, } \\
\text { namely, silver sulfadia- } \\
\text { zine at 1\%, rayon gauze, } \\
\text { burn gauze (cheese type), } \\
\text { absorbent cotton, and tape. } \\
\text { Dressing 3: 51\% calcium } \\
\text { alginate (guluronic acid), } \\
\text { 9\% carboxymethyl cellu- } \\
\text { lose, 32\% nylon, and } 8 \% \\
\text { elemental silver. }\end{array}$ & $\begin{array}{l}\text { The use of the conventional } \\
\text { four-layer dressing had worse } \\
\text { evolution of the areas of the } \\
\text { mixed second degree, possibly } \\
\text { due to the difficulty of changing } \\
\text { the dressing without removing, } \\
\text { at least partially, of the rayon } \\
\text { gauze. } \\
\text { The use of the silver hydro-algi- } \\
\text { nate dressing had superior res- } \\
\text { toration results when compared } \\
\text { to the conventional dressing in } \\
\text { mixed second-degree burns. }\end{array}$ \\
\hline
\end{tabular}




\section{DISCUSSION}

Of the studies mentioned, one of them stressed that hyaluronic acid had better results than the essential fatty acid, but this was observed in a single patient ${ }^{22}$. Another more recent study, from 2017, also highlighted the use of hyaluronic acid, but it was a single case report ${ }^{29}$.

Essential fatty acid (EFA) has been used in clinical practice as a preventive and for wound treatment for many years, and some brands on the market are considered correlated ${ }^{34}$. Linoleic acid and linolenic acid are the most important fatty acids for treating wounds, and EFA-based products may contain one or both and have, in addition, vitamins $\mathrm{A}$ and $\mathrm{E}$ and soy lecithin ${ }^{35}$.

A systematic review highlighted that the topical action of the combination of hyaluronic acid and silver sulfadiazine showed significantly favorable response in the mean time for healing of partial and deep-partial thickness burns ${ }^{12}$.

A study that analyzed 132 medical records of children aged zero to 14 years old, affected by burns, found that the results from nanocrystalline silver dressings and those associated with the non-traumatic interface of the wound and of absorbent foam were better than the silver sulfadiazine ${ }^{25}$. Metallic silver in the form of nanoparticles is a potent antimicrobial agent ${ }^{36}$, with a more powerful fast bactericidal capacity greater than sulfadiazine and silver nitrate-based dressings ${ }^{37}$.

In another study, conducted with 20 patients, researchers reported that in those who used collagenase (10 patients), the healing time was shorter than in those who used topical heparin (ten patients) ${ }^{26}$; sodium heparin, which is known for its anticoagulant action ${ }^{38}$. Researchers have pointed out that the effect of parenteral sodium heparin has been studied on thermal injuries in animals and in humans, with favorable effects ${ }^{26}$.

Other researchers, in a case study, revealed that the soft silicone and foam dressing is a good option for treating burns in joint areas, such as the hand, avoiding long immobilizations, retractions, and sequelae ${ }^{27}$. In research on 29 patients, it was reported that second degree burns epithelialized using the porous cellulose membrane, without the need of changing dressings. The authors emphasized that the membrane provides ease of application, excellent adhesion to tissues, reduction of pain, adequate visualization of the lesion, spontaneous drainage, reduc- tion or absence of dressing changes, and increased intervals of medical supervision ${ }^{28}$.

These studies cited used several topical therapies, and the results consist of a number of 184 patients, i.e., the sample was low.

In relation to hyaluronic acid, there were two cases presented, and a soft silicone and foam dressing was used in one case. Even though the authors highlighted good results, this is insufficient to assert that they are beneficial for burns ${ }^{27.29}$.

In relation to silver sulfadiazine $1 \%$, in the 132 patients studied, this type of therapy had lower results than nanocrystalline silver dressings and those associated with the non-traumatic interface of the wound and of absorbent foam ${ }^{25}$. In another study with 20 patients, sulfadiazine was also compared with silver hydro-alginate, which had the best results in the healing ${ }^{33}$. Nanocrystalline silver was also used in a study with eight patients and proved effective in the healing of burns ${ }^{32}$. One study presented the use of a compress soaked in a solution of 2 liters of warm water at a temperature between 38 and $40{ }^{\circ} \mathrm{C}$ and 200 $\mathrm{ml}$ of alcohol on the burn; however, only two cases were reported ${ }^{31}$. Researchers used Omiderm ${ }^{\circledR}$, a biosynthetic dressing that is a semibiological substitute of the skin in a study with patients and reported favorable results in the healing of burns. The product is transparent, adherent, and semipermeable therefore has the property to protect and maintain the moisture in the wound ${ }^{30}$.

\section{CONCLUSION}

We highlight, in this study, the good results obtained with porous cellulose membrane and nanocrystalline silver dressings in virtue of having been used in a larger number of patients in the 10 studies evaluated.

Many Brazilians suffer burns; however, in the literature, there are few articles that present the topical therapy used and its results. This study presented only 10 papers that met the inclusion criteria. Considering what was found in the literature, it is necessary to disseminate other studies showing the effectiveness of topical therapies, since burned patients are extremely vulnerable, suffer from hyperalgesia and have the injuries heal, often, after a long time, with retractions and impaired self-esteem.

There are more modern burn dressings, such as the Mepitel $^{\circ}$ (Mölnlycke), which has a double layer 
of silicone, with perforated aspect; Biatain Silicone ${ }^{\circledR}$ (Coloplast), an absorbent foam dressing with soft silicone; Mepilex ${ }^{\circledR} \mathrm{Ag}$ (Mölnlycke), a foam dressing with antimicrobial, with a bioburden-reducing action; Urgotul ${ }^{\circledR}$ (Urgo Medical), with a layer of flexible contact with the TLC healing matrix (made of flexible polyester mesh impregnated with a layer of carboxymeth- ylcellulose and lipophilic particles dispersed); the negative pressure therapy (NPT), which provides uniform subatmospheric pressure to the wound, whose mechanism of action involves biological and physical effects $^{39}$, among others, but no published studies were found on these dressings for the treatment of burns.

\section{RESUMO}

OBJETIVO: Identificar, por meio de revisão integrativa, estudos nacionais publicados nos últimos dez anos que destaquem produtos e terapêuticas utilizados nas queimaduras.

MÉTODOS: Pesquisa integrativa com estudos publicados nos últimos dez anos. Incluídos os estudos clínicos que descreveram a utilização de terapias já consagradas ou inovadoras em queimaduras e os resultados obtidos e publicados em periódicos nacionais nos últimos dez anos. Excluídos os artigos publicados antes de 2007 e os que não apresentaram resultados quanto ao uso de produtos nas queimaduras.

RESULTADOS: Selecionados dez artigos que atenderam aos critérios de inclusão, sendo colagenase, sulfadiazina de prata 1\% e membrana celulósica porosa algumas das terapias descritas.

CONCLUSÕES: A casuística foi baixa, porém, ressaltam-se os bons resultados obtidos com a membrana celulósica porosa e o curativo com prata nanocristalina, em virtude de terem sido utilizados em um maior número de pacientes nos estudos avaliados.

DESCRITORES: Queimaduras. Unidades de queimados. Cicatrização. Desbridamento. Bandagens.

\section{REFERENCES}

1. Ministério da Saúde (BR). Secretaria de Atenção à Saúde. Cartilha para tratamento de emergência das queimaduras. 2012 [citado 22 mai 2017]. Disponível em: http://bvsms.saude.gov.br/bvs/publicacoes/cartilha_tratamento_emergencia_queimaduras.pdf

2. Vale ECS. Primeiro atendimento em queimaduras: a abordagem do dermatologista. An Bras Dermatol. 2005;80(1):9-19.

3. Ferreira E, Lucas R, Rossi LA, Andrade D. Curativo do paciente queimado: uma revisão de literatura. Rev Esc Enferm USP. 2003;37(1):44-51.

4. Garcia AP, Pollo V, Souza JA, Araujo EJ, Feijó R, Pereima MJL. Análise do método clínico no diagnóstico diferencial entre queimaduras de espessura parcial e total. Rev Bras Queimaduras. 2011;10(2):42-9.

5. Greco Júnior IB, Moscozo MVA, Lopes Filho AL, Menezes CMGG, Tavares FMO, Oliveira GM, et al. Tratamento de pacientes queimados internados em hospital geral. Rev Soc Bras Cir Plást. 2007;22(4):228-32.

6. Lima RVKS, Coltro PS, Farina Júnior JA. Terapia por pressão negativa no tratamento de feridas complexas. Rev Col Bras Cir. 2017;44(1):81-93.

7. Brito T. Tratamento coadjuvante com oxigenoterapia hiperbárica em pacientes grande queimados. Rev Bras Queimaduras. 2014;13(2):58-61.

8. Bolgiani AN, Serra MCVF. Atualização no tratamento local das queimaduras. Rev Bras Queimaduras. 2010;9(2):38-44

9. Ferreira FV, Paula LB. Sulfadiazina de prata versus medicamentos fitoterápicos: estudo comparativo dos efeitos no tratamento de queimaduras. Rev Bras Queimaduras. 2013;12(3):132-9.

10. Ragonha ACO, Ferreira E, Andrade D, Rossi LA. Avaliação microbiológica de coberturas com sulfadiazina de prata a 1\%, utilizadas em queimaduras. Rev. Latino-Am. Enfermagem. 2005;13(4):514-21.

11. Moser H, Pereima RR, Pereima MJL. Evolução dos curativos de prata no tratamento de queimaduras de espessura parcial. Rev Bras Queimaduras. 2013;12(2):60-7.

12. Dalmedico MM, Meier MJ, Felix JVC, Pott FS, Petz FFC, Santos MC. Coberturas de ácido hialurônico no tratamento de queimaduras: revisão sistemática. Rev Esc Enferm USP. 2016;50(3):522-8.

13. Cruz AKM, Pereira WO, Santos EA, Carvalho MGF, Medeiros AC, Oliveira FW. Comparative study between the effects of hyaluronic acid and acid galactan purified from eggs of the mollusk Pomacea sp in wound healing. Acta Cir Bras. 2004;19(1):13-7.
14. Rossi LA, Menezez MA|, Gonçalves N, Ciofi-Silva CL, Farina-Junior |A, Stuchi RAG. Cuidados locais com as feridas das queimaduras. Rev Bras Queimaduras. 2010;9(2):54-9.

15. Dornelas MT, Ferreira APR, Cazarim DB. Tratamento das queimaduras em áreas especiais. HU Rev. 2009;35(2):119-26.

16. Costa VP, Mayworm MA. Plantas medicinais utilizadas pela comunidade do bairro dos Tenentes - município de Extrema, MG, Brasil. Rev Bras Plantas Med. 2011;13(3):282-92.

17. Agência Nacional de Vigilância Sanitária (ANVISA). Formulário de Fitoterápicos Farmacopeia Brasileira. 2011 [citado 2017 jun 26 ]. Disponível em: http://www.anvisa.gov.br/hotsite/farmacopeiabrasileira/conteudo/ Formulario_de_Fitoterapicos_da_Farmacopeia_Brasileira.pdf

18. Ministério da Saúde (BR), Portal da Saúde - SUS. Assistência Farmacêutica. Relação Nacional de Medicamentos Essenciais quase dobra [citado 2017 jun 05]. Disponível em: http://www.paho.org/bra/index.php?option=com_content \&view=article\&id=2799\%3Arelacao-nacional-de-medicamentos-rename-2012\&catid=844\%3Abra-02-c-noticias\&ltemid $=455$

19. Mendes KDS, Silveira RCCP, Galvão CM. Revisão integrativa: método de pesquisa para a incorporação de evidências na saúde e na enfermagem. Texto Contexto Enferm. 2008;17(4):758-64.

20. Montes SF, Barbosa MH, Sousa Neto AL. Aspectos clínicos e epidemiológicos de pacientes queimados internados em um Hospital de Ensino. Rev Esc Enferm USP. 2011;45(2):369-73.

21. Colaço AD, Lima CSP, Pinho FM, Costa GD, Klein TCR. O curativo do grande queimado em unidade de terapia intensiva: relato de experiência. Rev Enferm UFPE on line. 2013;7(esp):4287-91.

22. Pinho FM, Amante LN, Salum NC, Silva R, Martins T. Guideline das ações no cuidado de enfermagem ao paciente adulto queimado. Pesquisa de campo/ Revisão integrativa. Rev Bras Queimaduras. 2016;15(1):13-23.

23. Guerra ACPCS, Antunes MPS, Ferreira JPA, Reis GMD. Queimadura com exposição óssea dos membros inferiores: reconstrução com matriz de regeneração dérmica. Rev Bras Cir Plást. 2011 26(1):174-80.

24. Gonçalves N, Franzolin RA, Oliveira PG, Castilho |C. Comparação dos efeitos do ácido hialurônico $0,2 \%$ e ácidos graxos essenciais em paciente com queimadura por fertilizante: relato de caso. Rev Bras Queimaduras 2016;15(3):175-8. 
25. Moser HH, Pereima MJL, Soares FF, Feijó R. Uso de curativos impregnados com prata no tratamento de crianças queimadas internadas no Hospital Infantil Joana de Gusmão. Rev Bras Queimaduras. 2014;13(3):147-53.

26. Teles GGA, Bastos JAV, Amary A, Rufatto LA, Ritty RS, Broglio LAP, et al. Tratamento de queimadura de segundo grau superficial em face e pescoço com heparina tópica: estudo comparativo, prospectivo e randomizado. Rev Bras Cir Plást. 2012;27(3):383-6.

27. Proto RS, Gozzano RN, Brasileiro F, Moreira SS, Gonella HA. Curativo de espuma e silicone suave: uma alternativa para o tratamento de queimadura em mãos. Rev Bras Queimaduras. 2012;11(2):100-2.

28. Vieira JC, Badin AZD, Calomeno LHA, Teixeira V, Ottoboni E, Bailak M, et al. Membrana porosa de celulose no tratamento de queimaduras. Ara Catarinenses Med. 2007;36(supl. 1):94-7.

29. Silva MN, Damiani GV, Masson VA, Calil SR, Volpato V, Gonçalves N, et al. Efeitos do tratamento tópico com ácido hialurônico 0,2\% em queimadura de segundo grau: um relato de experiência. Rev Bras Queimaduras. 2017;16(1):49-52

30. Buelvas AM, Ohana BB. Uso de Omiderm ${ }^{\circledast}$ em queimadura grave. Rev Bras Queimaduras. 2016;15(1):50-3.

31. Calegari I, Queiroz Venancio EQ. O princípio da similitude no tratamento de queimaduras. Cadernos ABEM. 2012;8:43-51.

32. Costa Filho MAR, Ferreira RB, Nunes BB, Bortolucci GAP, Proto RS, Gozzano RN, et al. Tratamento ambulatorial de queimaduras com prata nanocristalina em malha flexível: uma alternativa terapêutica. Rev Bras Queimaduras. 2012;11(4):226-9.

33. Rocha FS, Sakai RL, Simão TS, Campos MH, Pinto DCS, Mattar CA. Avaliação comparativa do uso de hidroalginato com prata e curativo convencional em queimaduras de segundo grau. Rev Bras Queimaduras. 2012;11(3):106-10.

34. Agência Nacional de Vigilância Sanitária (ANVISA). Registro ANVISA n. 80225200008. [citado 2017 jun. 18]. Disponível em: https://www.smerp. com.br/anvisa/?ac=prodDetail\&anvisald= 80225200008

35. Ferreira AM, Souza BMV, Rigotti MA, Loureiro MRD. Utilização dos ácidos graxos no tratamento de feridas: uma revisão integrativa da literatura nacional. Rev Esc Enferm USP. 2012;46(3):752-60.

36. Silva MMP, Aguiar MIF, Rodrigues AB, Miranda MDC, Araújo MAM, Rolim ILTP, et al. Utilização de nanopartículas no tratamento de feridas: revisão sistemática. Rev Esc Enferm USP. 2017;51:e03272.

37. Moreira SS, Macedo AC, Nunes BB, Brasileiro FF, Guarizzo |, Gozzano R, et al. Implantação de nova tecnologia para otimização do atendimento em ambulatório de queimados, sem adição de custos. Rev Bras Queimaduras. 2013;12(2):87-102

38. Junqueira DRG, Viana TG, Peixoto ERM, Barros FCR, Carvalho MG, Perini E. Farmacovigilância da heparina no Brasil Rev Assoc Med Bras. 2011;57(3):328-32.

39. Lima RVKS; Coltro PS, Farina Júnior JA. Terapia por pressão negativa no tratamento de feridas complexas. Rev Col Bras Cir. 2017;44(1):81-93. 